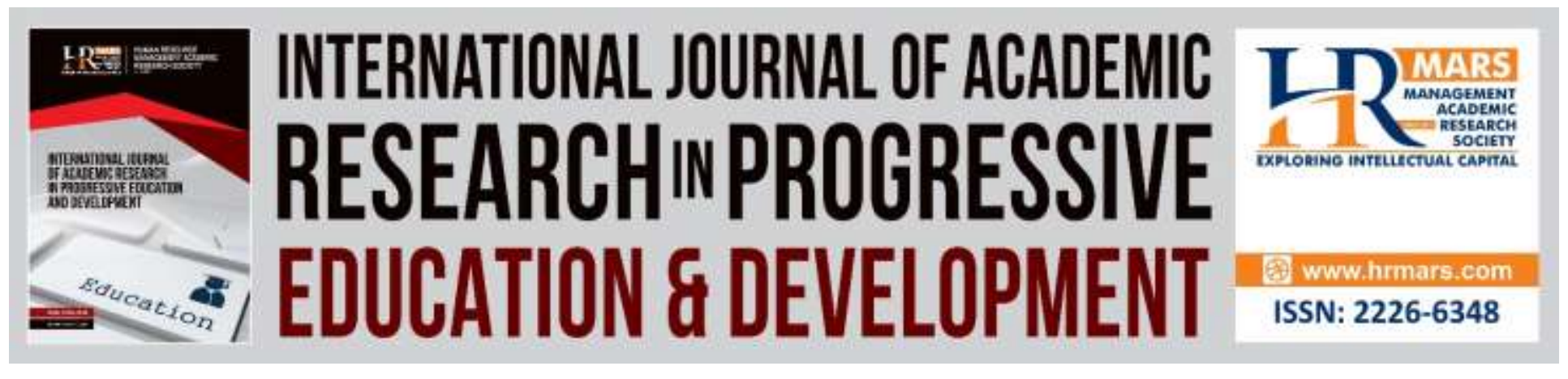

\title{
An Analysis of Writing Competency Principle and its Problem in Essay Writing
}

Noor Hidayah Binti Ismail, Azhar Bin Md Sabil

To Link this Article: http://dx.doi.org/10.6007/IJARPED/v8-i4/6910

DOI:10.6007/IJARPED/v8-i4/6910

Received: 19 October 2019, Revised: 11 November 2019, Accepted: 29 November 2019

Published Online: 30 December 2019

In-Text Citation: (Ismail \& Sabil, 2019)

To Cite this Article: Ismail, N. H. B., \& Sabil, A. B. M. (2019). An Analysis of Writing Competency Principle and Its Problem in Essay Writing. International Journal of Academic Research in Progressive Education and

Development, 8(4), 1103-1109.

Copyright: (C) 2019 The Author(s)

Published by Human Resource Management Academic Research Society (www.hrmars.com)

This article is published under the Creative Commons Attribution (CC BY 4.0) license. Anyone may reproduce, distribute, translate and create derivative works of this article (for both commercial and non-commercial purposes), subject to full attribution to the original publication and authors. The full terms of this license may be seen at: http://creativecommons.org/licences/by/4.0/legalcode

Vol. 8(4) 2019, Pg. 1103 - 1109

http://hrmars.com/index.php/pages/detail/IJARPED

JOURNAL HOMEPAGE

Full Terms \& Conditions of access and use can be found at http://hrmars.com/index.php/pages/detail/publication-ethics 


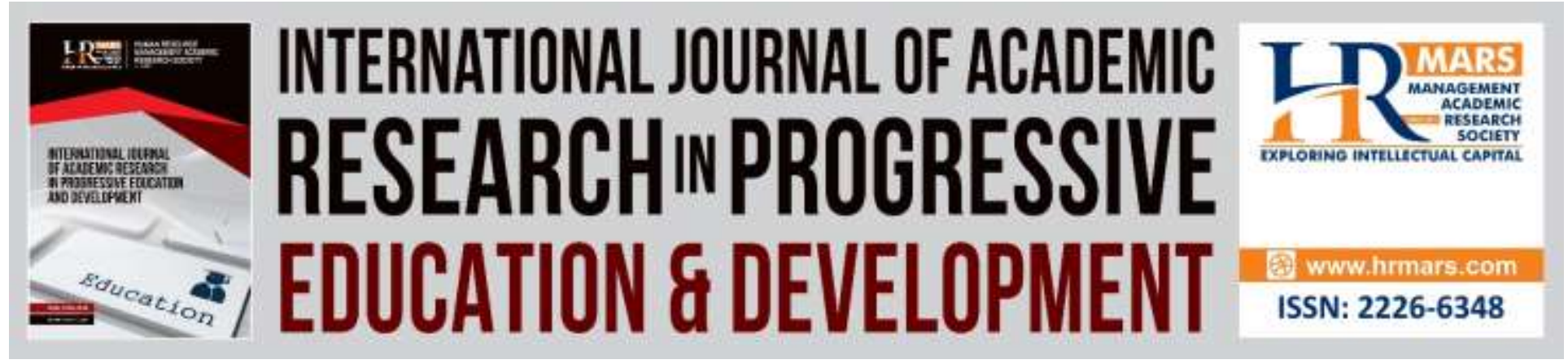

\title{
An Analysis of Writing Competency Principle and its Problem in Essay Writing
}

\author{
Noor Hidayah Binti Ismail, Azhar Bin Md Sabil \\ Department of Language and Humanities Education, Faculty of Educational Studies \\ Universiti Putra Malaysia, Serdang, Malaysia
}

\begin{abstract}
This research aims to analyze an essay based on the principles of essay writing competency. The present study looks at the perspective of writing excellence, which is to achieve writing principles in creative work. Previous researches have found that students are still poor at mastering the good writing competency when they fail to convey messages through written communication. Therefore, this essay will focus on the principles of essay writing. The title of the essay is global and is well known for its content and discussion. This research is in the qualitative form by taking sample essays from IPTA students. Based on the principles of writing competency, Mohd Sidin Ahmad Ishak (1992) in his research has found that samples have good writing skills and require exposure to produce the highest quality of writing.
\end{abstract}

Keywords: Essay Writing Competency, Writing Problem, Student

\section{Introduction}

Competency means an efficient matter or the ability of someone to attract the around attention with a good performance. The writing competency refers to one's ability to express ideas with mature ideas, the use of multiple vocabularies, the right vocabulary and to convey feelings directly to the reader through effective writing.

Therefore, the writing competency is compulsory to be mastered by the students because according to Taringan (2003), the writing competency helps the students to widen their thinking, deepen their thinking, improve their thinking skills and be able to overcome problems encountered in their study.

\section{Seven Principles of Writing Competency}

Principles of writing competency are pioneered by Mohd Sidin Ahmad Ishak (1992). His principle focuses on seven principles that must be present in producing an essay. Many of his works include essays, articles, magazine, newspaper analysis and more. In regards to the aspect of cohesion studied by Sidin, this cohesion is actually one of the most important branches of discourse theory 
pioneered by Henry Guntur Tarigan. However, Sidin has argued that part of the theory of discourse (cohesion) so deeply that new principles of writing are formed. The principles of writing can be seen in the following diagram.

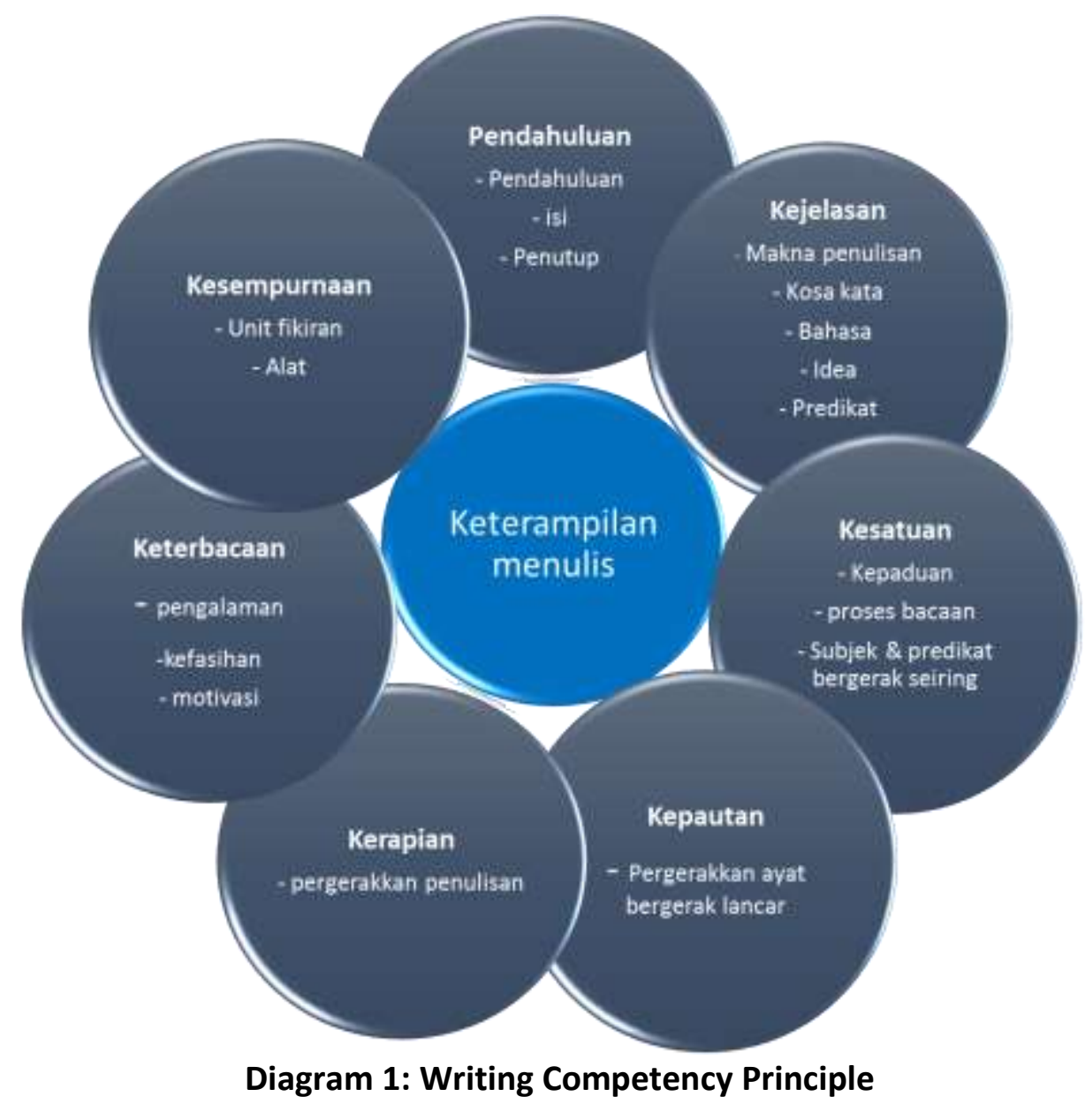

All these elements need to be created within an essay produced to in order to be recognised to achieve a great level of writing style.

\section{Paragraphing}

A paragraph must have a paragraph as well as an essay that has its own purpose. Paragraph construction is an important task in any essay. Every idea which needs to be conveyed must be in the small units of the paragraph so that the units come together, so there is an essay that contains ideas on the theme you which needs to be conveyed. The paragraph can be divided into a few types which are:
a. Introduction paragraph
b. Closing paragraph
c. Content paragraph
d. Transition paragraph 
Vol. 8, No. 4, 2019, E-ISSN: 2226-6348@ 2019 HRMARS

\section{Clarity}

e. Dialog paragraph

A clear paragraph gives the meaning of a clear, concise and easily understood idea of writing. There are many reasons why a piece of writing is unclear. This can be seen from word selection, sentence construction and idea coordination. Clarity can be understood through the proper use of language and not jumble.

An example of clarity is also understandable to whom this text is intended and the terms used describe the proficiency of lots of vocabularies although the use of the too high level of vocabularies will interrupt the reader's understanding of the content of the author.

\section{Coherent and Cohesion}

A paragraph is said connected when the sentences are clear and people are able to read them easily from one sentence to another with no empty space or mind gap or the idea left unsubmitted. The use of good coherent and cohesion in an essay can be seen through sentence arrangement in a paragraph logically connected and integrated during the explanation of the idea and thought.

The writer's focus on what is to be conveyed will streamline the writing process as the writer knows that his mind is moving from one information to another. Unity can be a problem if the writer is trying to get an idea through a sentence. Among the problems that will be encountered is clear disruption in the sequence of ideas due to the presence of irrelevant thoughts and the gradual distortion of the purpose of the actual paragraph. This is because the author intentionally lets the verse move to another direction.

Meanwhile in the kohesi, the author should explain the information in detail so that the reader is not surprised by the question that plays in the mind of the reader. There is no blank space or idea left by the author in his writing. A weak paragraph in unity, indirectly weak in its kohesi. The weakness of the union is due to the weakness of the reference to the topic verse, the weakness of the kohesi is due to the weakness of the reference to the previous verses. Typically, in the kohesi there are three transition tools or they are also referred to as connecting devices which are pronouns, word repetition and transition marker.

\section{Perfection}

Perfection in this study is a complete unit of mind. In other words, the paragraph has carried out the expected tasks of developing its topic idea completely. After the reading of the paragraph or text, the reader will be satisfied and not surprised by what is described. The tools used to create perfection in writing include supporting details, examples, comparisons and so on. Incomplete paragraphs are the opposite. It does not have things to develop or it is not enough. The topic paragraphs mentioned in the article are not properly described.

\section{Readability}

This is related to the reading processes which are understanding, fluency and interest. Understanding is not related to the meaning of the printed text but rather depends on the reader's fluency and the attraction or the reader's interest in the material read. It is clear that reading depends on the content of the writing, if the subject matter is unfamiliar to the reader it 
will be difficult to read. The writing also depends on verse selection and sentence structure. In this principle of readability, there are three factors, namely the author's ability to connect the material read with the reader's experiences and fluency which is to what extent that the reader can read at an optimal rate. Both of these factors should be possessed by the reader if they want to understand the source of the read. Next, the third principle refers to motivational factors that affect the interest and the desire to keep reading. It is clear that in the principle of readability, it depends on the content of the text, if the material is unfamiliar to the reader, the understanding of the material will be difficult to read and understand. It depends on the choice of words and sentence structure.

\section{Neatness}

There are various ways to create neatness value in writing. A certain sequence needs to be used to ease the reader to follow the flow of thought and idea of the writer. Among the sequences are:

- $\quad$ Time sequence

- $\quad$ Space sequence

- Inductive sequence

- Deductive sequence

- $\quad$ sebab From question to answer / From the effect to cause

This research focuses on the concept of writing production through structured training. Therefore, the writing competency through this research means a writing technique that has good writing principles and is well-prepared before writing, checklist (key content), selection of appropriate writing material, systematic and containing text analysis in analysis discourse. In other words, the principle of writing needs to be adhered to, carefully arranged and combined with the absorption of other components such as verse selection, analysis, design, execution and next to achieve the intended purpose.

\section{Problem in Writing}

Several issues have been identified in writing that involve the principle in writing. It is in line with educational goals to ensure students are able to produce a wide variety of creative writing related to personal knowledge and experience using grammatical sentences, correct punctuation and spelling, as well as clear and neat writing. Based on the researches conducted by some scholars, there are many problems frequently done by the students found in such researches, including studies by Hassan \& Rahman (2011); Salleh, Jusoh, Embong, \& Mamat, (2018); Tzotzou, (2016); Kai, Rahman, (2018) have found that some of the reasons students fail to achieve good writing levels including the failure to adhere to the aspect of paraphrasing in writing while the first principle outlined is paraphrasing. The factor of students 'weakness in adhering to the principles of writing in terms of paraphrasing is also acknowledged by Baki (2003) who states students' weaknesses in producing an essay are content, language and writing. 
In terms of clarity, it can be seen from the student performance reports issued by the Ministry of Education Malaysia and the Malaysian Examination Board (2012) when reports indicate about the lackness of students in presenting ideas. The problem of lack of content and irrelevant content, as well as the content does not meet the requirement of the question has hindered communication to be clearly communicated. Cohesion and coherence problems are closely related to problems in writing. Students' weakness in applying aspects of cohesion and coherence in writing is a problem that must be addressed for students to produce quality essays and meet the principles of writing competency. Hamid (1997) also in her research showed evidence that students are having trouble mastering cohesion and coherence knowledge when she finds that students are unable to produce cohesion sentences in their essay writing. This is strengthened by a research conducted by Jalil (2000), who explained that in his study most students were not able to produce good writing in terms of linkage. Superficial knowledge of the aspect of cohesion causes students to not know how to use cohesion well even when they understand the concept. There are still weaknesses in the students' ability to produce neatly written essays in content, language and writing. Students' weakness in writing essays can be seen from the point of absence of sequences from one time to another. The lack of chronology of the story causes the reading process to be interrupted. In the next principle of perfection, perfection is essential to keep the reader satisfied and not surprised by what the author is trying to convey. However, students' weakness in mastering this aspect can be seen in a research by Aziah (2016) that writers need to know what they want to write and choose the right words for the sentences to be varied and grammatical. Based on the statement stated, it is clearly shown that in each research the participants did not fully meet all of the competencies listed.

\section{Conclusion}

Writing competency is an important aspect of producing writing. Without the presence of writing principles in an essay, the communication cannot be clearly communicated and readers will inquire many questions that lead to misunderstandings in communicating the ideas. The correct use of grammar, punctuation and spelling contributes to the quality of the essay upon producing an essay.

\section{Acknowledgement}

Infinite thanks to all family members, lecturers in the Faculty of Education (FPP), UPM Serdang, teachers and all parties involved directly and indirectly in the course of this study. Thank you very much to the school management as well for cooperating throughout this research process. Support from all involving parties has helped to complete this study successfully.

\section{Corresponding Author}

Noor Hidayah binti Ismail

School of Educational Studies, Universiti Putra Malaysia, Serdang

MALAYSIA

Email: hakhidayah@gmail.com 
INTERNATIONAL JOURNAL OF ACADEMIC RESEARCH IN PROGRESSIVE EDUCATION AND

DEVELOPMENT

Vol. 8, No. 4, 2019, E-ISSN: 2226-6348 @ 2019 HRMARS

\section{References}

Omar, A. H. (1982). Language and society in Malaysia. Kuala Lumpur: Dewan Bahasa dan Pustaka.

Bachman, L. F. (1990). Fundamental considerations in language testing. Oxford: Oxford University Press.

Chapakia, F. C. B. O. (2008). Amalan Pengajaran Bahasa Melayu di Sekolah Agama Rakyat Selatan Thailand: Kajian Kes di Sekolah Muslim Phatanasad. Tesis Master. Universiti Malaya Kuala Lumpur.

Musa, H. H. (2008). Hati Budi Melayu Pengukuhan Menghadapi Cabaran Abad ke-

21.Universiti Putra Malaysia.Serdang

Musa, H. H. (1993). Binaan Dan Fungsi Perkataan Dalam Bahasa Melayu Suatu Huraian Dari Sudut Transformasi Generatif. Kuala Lumpur : Dewan Bahasa dan Pustaka.

Idris, N. (2013).Penyelidikan Dalam Pendidikan. Mc Graw Hill Education

Henry Guntur Tarigan.(1995). Pengajaran Wacana. Kuala Lumpur : Dewan Bahasa dan Pustaka.

Ishak, M. S. A. (1992). Ketrampilan Menulis. Kuala Lumpur : Dewan Bahasa dan Pustaka.

Aman, I. (2010). Analisis Wacana. Bangi. Universiti Kebangsaan Malaysia.

Jusoh, Z. B. (2009). Keberkesanan Ternik Bercerita Dalam Pengajaran Dan Pembelajaran Karangan Naratif Bahasa Melayu. UPM Serdang.

Salleh, M., Jusoh, A., Embong, R., \& Mamat, M. (2018). Learning Organizational Model in the 21th Century Classroom at Sultan Mahmud Science Secondary School in Terengganu, Malaysia. International Journal of Academic Research in Progressive Education and Development, 7(4), 410-426.

Ismail, N. H. B., \& Sabil, A. B. M. (2019). An Analysis of Writing Competency Principle and Its Problem in Essay Writing. International Journal of Academic Research in Progressive Education and Development, 8(4), 977-983.

Tzotzou, M. D. (2016). Content and Process of the Major Training Programme for State EFL Teachers in Greece: A Critical Review. Multilingual Academic Journal of Education and Social Sciences, 4(1), 13-23.

Kai, D. K., Rahman, B. A. I. (2018). The Impact of Financial Indicators towards Stock Returns of Finance Companies Listed on Bursa Malaysia, International Journal of Academic Research in Accounting, Finance and Management Sciences 8 (3): 128-140. 